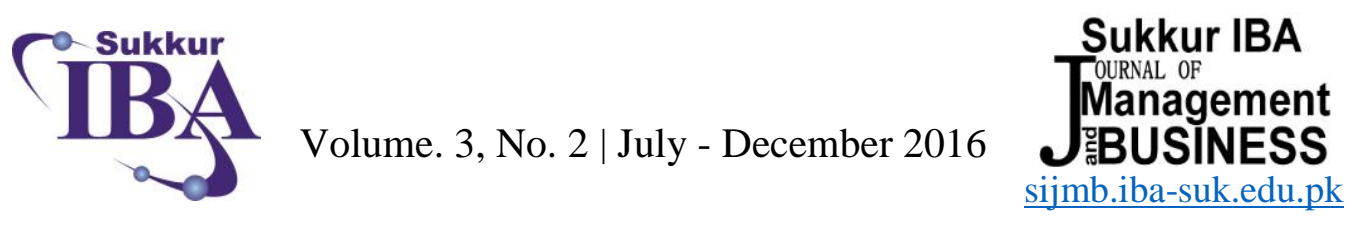

\title{
Organization Justice and Organization Citizenship Behaviour: Employee Trust Acting as Mediator Rezwan Ullah ${ }^{* 1}$
}

Department of Business Administration, Institute of Management Sciences, Peshawar Syed Zubair Ahmad

Member Board, Islamabad Chapter, Association of Certified Fraud Examiners, USA

Sahibzada Yaseen Ahmad

Department of Management Sciences Bahria University Islamabad

\begin{abstract}
:
Justice in the organizations mostly focused on two perspectives, fairness of results and fairness of techniques is used to determine that outcomes and the perspectives were called as distributive justice and procedural justice respectively. The organizational justice covers everything on versatile concept from system of payment to treatment of your boss. Researchers of organizational behaviour recognized four types of organizational justice that is procedural, distributive, interactional and informational justice. Procedural justice perceptions considered to be one of the most crucial variables of organizational justice perceptions. The effect of different level of organizational justice on organizational citizenship behaviour is a widespread researched topic and explains the importance of organizational justice in an organization. The purpose of this quantitative study is to investigate the impact of employee trust on the relationship between organizational justice and organizational citizenship behaviour in the perspective of call centre industry in Pakistan. The sample size covered 160 employees of different call centres of Islamabad. A total of 38 questions were asked based on a 5 point Likert scale responses. For accurate data processing, SPSS Statistics software package is used for statistical analysis. Regression is used to test the hypothesis. The results show that there is a positive relationship between Organizational Justice and OCB (Accepted), there is a positive relationship between Procedural Justice and OCB (Rejected), there is a positive relationship between Distributional Justice and OCB (Accepted), there is a positive relationship between Interactional Justice and OCB (Accepted) and employee trust does not mediate the associations between Organizational Justice and OCB, which is a positive effects on OCB.
\end{abstract}

Keywords: Organizational citizenship behaviour, Procedural Justice, Distributive Justice, Interactional justice, Employee trust.

https://doi.org/10.30537/sijmb.v3i2.100

${ }^{*}$ Corresponding Author

1 rezwanullah1990@yahoo.com

SIJMB | E-ISSN: 2410-1885; P-ISSN: 2313-1217 @ 2016 Sukkur Institute of Business Administration - All rights reserved 


\section{Introduction}

Organizational citizenship behaviour (OCB) has been studied since the late 1970s and the concept has been gaining momentum in diverse areas from personality/social psychological perspective to an organizational setting. Organ (1988), defined as an individual, voluntary and arbitrary behaviour not being identified directly and evidenced by the formal rewarding system and, generally, it improves the effective operation of the organization. Adam's theory of the fairness Adams (1965) emphasizes that the people always assess themselves in the context of the area and in equivalence alongside others. The thoughts of the fairness and fairness in the organizational settings denote organizational justice.

The word "justice" in the various environments carries the different consequences for individuals and groups. The concept of the justice in the organizations originates from the discussions related to the social psychology of relationship to distributive justice. Organizational justice represents the person and the cluster's observations of the justice of conducting acknowledged from establishments and their interactive responses to such opinions James (1993).

Procedural justice refers to the observed fairness of the procedures used to conclude result circulations or distributions Colquitt, Conlon, Wesson, Porter, and Ng (2001). While procedural justice can be raised through numerous rules, such as uniformity rule, bias-suppression regulation, accurateness rule, correct ability regulation, the representativeness rule, and ethicality rule, research had used regularly all or some of these.

Trust is a vital constituent of interpersonal relations; in fact, the existence of a social group may be topic to on the members' willingness to exercise trust with one another. The capacity to introduction a sense of self-worth, to have the esteem of co-workers and to like healthy social relatives is secure in trust Hodson (2002).

Organization justice has been shown to be related to employee attitudes as well as trust in the organization. It has been found that organizational justice was an important predictor of trust. They drawing on 28 in-depth interviews found that a general perception of organization justice had some influence on feelings of trust Aryee, Budhwar, and Chen (2002).

Various researchers have been led on administrative fairness in the US Greenberg (2002). Yet, very less number of readings has been conducted in Asian perspective Loi, Hang-Yue, and Foley (2006). This means that the miracle should be verified in supplementary sophistications McFarlin and Sweeney (1992). Greenberg (2002), clashed that leading Cross-cultural studies in the span of organizational fairness will develop new visions into the phenomenon of justice and also theory will be tested in generalizability, and better theories will be developed. By assuming that our current

Sukkur IBA Journal of Management and Business | Volume 3 No. 2 July - December 2016 @ Sukkur Institute of Business Administration 
understanding of workplace fairness is universal, we overlook the deep cultural differences that can exist between people of the different nation. Therefore, another main reason behind conducting this study is to determine how four factor model of organizational justice influence the call centre industry in Pakistan.

\section{Literature Review}

\subsection{The term Organizational Citizenship Behaviour (OCB)}

The term organizational citizenship behaviour was for the first time used by Smith, Organ, and Near (1983), over a decade ago. They described the OCB as a behaviour of the organization that creates willingness of the employees to go beyond the required capabilities. Organizational citizenship behaviour has been considered to be one of the most important factors influencing organizational effectiveness Organ, Podsakoff, and MacKenzie (2005).

Organizational citizenship behaviour has undergone delicate definitional revisions since the term was coined in the late 1980s, but the construct remains the same at its core. OCB refers to anything that employees choose to do and may not always be directly and formally known or rewarded by the company, through salary increases or promotions, for example, though of course OCB may be replicated in favourable supervisor and co-worker ratings, or better performance reviews. In this way, it can ease future reward gain ultimately. Finally, and critically, OCB must 'promote the efficient execution of the organization Organ (1988).

Organ (1988), suggested that high levels of OCB should lead to the effective association and help to carry new capitals into the association. Organ (1988) argued that OCB has five main aspects that are Courtesy: to respect others, Altruism, it means that to help the colleagues at workplace, Sportsmanship means to bear in unfavourable conditions and showing a positive reaction without giving the chance of complaints, Civic virtue to make the employee dimension of organization good-well and finally Conscientiousness means performing direct role for organization success. OCB has main two types; OCBI the employees' attitude that gives direct benefits to them and as well as advantageous for the organization. Whereas OCBO the behaviours which thoroughly favour the organization Williams and Anderson (1991).

In 1930 the OCB remained an area of interest of a wide range of studies. The degree of willingness to get work from employees was initially introduced by $(\mathrm{OB})$ by Chester Barnard. Organizational citizenship behaviours are such behaviours which neither worked for rewarding the employees nor the forced the employees to exhibit such behaviours. Moreover, OCB only provides with the overall effectiveness of the organization is the behaviour that provides with lots of effectiveness to the organization, but doesn't favour the employees Aslam and Sadaqat (2011).

It has been founded by a meta-analysis that distributive justice is a central forecaster of

Sukkur IBA Journal of Management and Business | Volume 3 No. 2 July - December 2016 @ Sukkur Institute of Business Administration 
OCB Colquitt et al. (2001). In the perspective of the social exchange process, when employees realize fair treatment and believe in managers, they perform more than their capacities for the betterment of the organization even that aren't included in their job descriptions Deluga (1994).

\subsection{Organizational Justice}

Justice is a topic of philosophical research from the age of Plato and Socrates (Ryan, 1993). The word justice means "righteousness". Justice in the organizations, mostly focused on two perspectives, fairness of the results and fairness of techniques is used to determine that outcomes and these perceptive were called as distributive justice and procedural justice respectively Leventhal (1976). Organizational justice theory Greenberg (1987) emphasizes on positive attitudes in the organization, by categorizing employees' opinions and feelings regarding their treatment compare to others within the organization.

Organizational justice has been appearing as the latest topic on the debate panels for long in HRM, organizational psychology, and organizational performance. Organizational justice basically clarifies the equality insights of persons or of the group and then their conduct can be detected affording the action they receive from their association. It has been studied and projected that organizational justice would be at the top in organizational performances. It has been understood that organizational justice observations were powerfully connected to organizational promise and managerial associated commitment Greenberg (1990).

Greenberg (2005), organizational justice can be defined as "the study of people's opinions of justice in organization". The organizational justice covers everything on a versatile concept of a system of payment for the treatment of your boss. Researchers of organizational behaviour recognized four types of organizational justice that are procedural, distributive, interactional and informational justice Colquitt, Greenberg, Zapata-Phelan, Greenberg, and Colquitt (2005).

The organizational justice has a positive impact on OCB. The employees that find their organization unbiased and fair in processes, distribution and information system, they are more inclined to show organizational citizenship behaviours which are helpful in the progress of an organization Aslam and Sadaqat (2011).

\subsubsection{Procedural justice}

Employees are not only concerned about fair results, but also concerned with a fair process for the determination of their results. Procedural justice as justice issues relating to the techniques, mechanisms, and procedures employed to conclude results. This is a term used to describe the role of fairness in the workplace. Generally, they have identified two major perspectives on which justice research has typically focused: distributive justice and procedural justice Ang, Van Dyne, and Begley (2003).

Sukkur IBA Journal of Management and Business | Volume 3 No. 2 July - December 2016 ○ Sukkur Institute of Business Administration 
Procedural justice perceptions considered to be one of the most crucial variables of organizational justice perceptions. Workers seem to be more dissatisfied when they perceive that the main hurdle is a procedure in the way of receiving their rewards for their performance. By adopting fair procedures, the negative outcomes of unfair procedures will be avoided.

Moreover, in the case of procedural injustice people did not only consider their outcomes as unfair but also reject the entire system by considering that unfair Cropanzano, Ambrose, Greenberg, and Cropanzano (2001). People's tendencies to follow company rules were found to be affected by procedural justice practices; therefore, top level officials were advised to promote procedural justice, so it would be easy for employees to follow company rules Greenberg and Baron (2008). An instrumental model by Thibaut and Walker (1978) proposed that procedural justice resulted in more controllable and predictable outcomes so it was highly valued.

\subsubsection{Distributive Justice}

Distributive justice means fairness in the distribution of rewards and benefits. Different researchers defined this dimension of organizational justice differently. Distributive justice can be defined that the individual's opinion on whether the gains they earned are distributed fairly. Individuals comparing their outcome to their previous outcomes or to the outcomes of the others by making judgments on the appropriateness of justice distributive Cohen-Charash and Spector (2001).

According to the Greenberg and Baron (2008), distributive fairness means "the form of organizational justice that emphases on people's views that they have received fair amounts of valued work-related outcomes (e.g. pay, recognition, etc.)". The effect of different level of organizational justice of organizational citizenship behaviour is a widespread researched topic and explains the importance of organizational justice in an organization.

\subsubsection{Interactional Justice}

Interactional fairness is a vital characteristic of prosperous organizations; it means that workers notice that they are preserved justly by their bosses. It is also connected to the proper presentation of the proper decision-making process. This kind of organizational fairness is described as "Interpersonal justice means people's perceptions of the fairness of the manner in which they are treated by others Greenberg and Baron (2008).

The theory of interaction justice has been established and expanded repeatedly along with the expansion of the theory of organizational justice. Adams first puts onward the fairness theory, signifying that when observing the justice of the outcomes, persons would work out the ratio of their input and output and compare their distributive outcomes with theirs (internal and external) and others Adams (1965).

Sukkur IBA Journal of Management and Business | Volume 3 No. 2 July - December 2016 ○ Sukkur Institute of Business Administration 
The theory of interactional justice has been established and expanded repeatedly along with the expansion of the theory of organizational justice. Adams first puts onward the fairness theory, signifying that when observing the justice of the outcomes, persons would work out the ratio of their input and output and compare their distributive outcomes with theirs (internal and external) and others Adams (1965).

\subsection{Employee Trust}

The concept of trust has been studied in various fields of social sciences. Trust is observed as a direction apparatus dropping social compound in sociology. In economics, trust is preserved as financial oil, dropping the business cost among conversation gatherings. In organizational science, trust has the result of leading risktaking in interpersonal relations. It has also clarified that a high level of trust between labour and management is a significant ancestor of a supportive association design and plays a vital role in the integrative negotiation and joint problem solving Fox (1974).

Furthermore, research has concentrated on various particular aspects of trust, including initial trust formation, the relationship between a Trust or and a Trustee Zand (1996).

Trust is a vital constituent of interpersonal relations; in fact, the existence of a social group may be topical to on the members' willingness to exercise trust with one another. The capacity to introduce a sense of self-worth, to have the esteem of co-workers and to like healthy social relatives is secured in a trust Hodson (2002).

Aryee et al. (2002), observed the potential facilitating effect of the trust in workers on the connection between organizational justice and worker work performances among a sample of Indian labours. They recognized three magnitudes of organizational justice (procedural, distributive and interactive) of trust in workers. These, in turn, differentiate connected to worker work consequences. They found incomplete provision for their proposals in the wisdom that the trust would completely, but in a dissimilar way arbitrate the association between the organizational justice and the work performances.

The mediating role of trust is based on the social exchange theory. The exchange is perhaps the most basic form of communal interaction, focusing the theoretical gap, e.g., subjective cost-benefit analysis and comparison of alternatives. Social exchange is grounded on the norm of joint benefit, namely we help those who help us Gouldner (1960).

Thus, Lewicki, Wiethoff, Tomlinson, Greenberg, and Colquitt (2005) delineated various studies that confirm that belief in other people and organizations grows along with fair treatment, these studies have shown that belief is a consequence of distributive, procedural and interactional justice.

Sukkur IBA Journal of Management and Business | Volume 3 No. 2 July - December 2016 @ Sukkur Institute of Business Administration 
Organizational fairness arose in belief in employees' that in turn inspires them to display more OCBs. The results of fairness and belief in supervisor on the OCB are examined on the academicians between public universities in Turkey. This displays that belief in supervisor replaced as a mediator in the connection of organizational fairness and OCB Aryee et al. (2002).

Thus, consenting that OCB is included between such contributions, it is counselled that the extent of that belief is an indicator of communal transactions; belief will arbitrate the connection amid organizational fairness and OCB. Therefore, with the aid of works we can say that organizational fairness will have to manage the result of organizational citizenship behaviour as belief is arbitrating between the two variables.

\section{Research Framework}

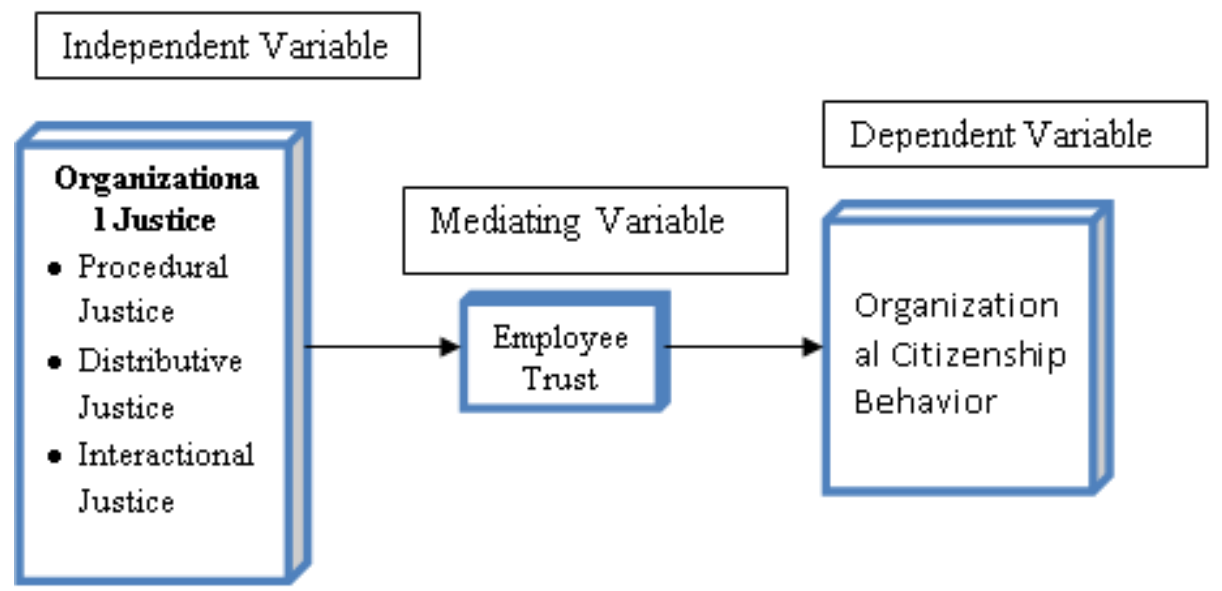

Figure: 1 - Theoretical Framework

\subsection{Research Hypothesis}

H1: Organizational Justice has positive impacts on $O C B$.

H 2: Procedural Justice has positive impacts on $O C B$.

H 3: Distributional Justice has positive impacts on $O C B$.

H 4: Interactional Justice has positive impacts on $O C B$.

H 5: Employee trust mediates the associations between Organizational Justice and $O C B$, which are positive impacts on $O C B$.

\section{Research Methodology}

\subsection{Research Instrument}

Quantitative methodology is adopted for the research, whereas method utilized is the survey through a structured and closed ended Questionnaire. The main reason for the use of survey research is the successful application of survey research in business research. This study resolve is an empirical analysis to see the effects of organizational

Sukkur IBA Journal of Management and Business | Volume 3 No. 2 July - December 2016 @ Sukkur Institute of Business Administration 
justice on organizational citizenship behaviour in the Call centre industry in Pakistan. The reason for selecting the call centre industry is because having great potential and little research work has been done in this industry. The mediating role of the employee trust was also analysed. The scale is based on 5 point Likert scale ranging from strongly disagree (1) to strongly agree (5). A total of 38 items were used to assess organization citizenship behaviour, distributive justice, procedural justice, interactional justice and employee trust.

\subsection{Sample and Data Collection}

The research aimed to determine the effects of organizational justice on organizational citizenship behaviour: the mediating role of employee trust. The total number of 160 questionnaires were distributed among the employees in which 100 were returned and 17 were eliminated due to excess missing data, 25 were empty because they refused to fill it and 18 was not filled correctly. Therefore, for the present research the size of sample become 100 for hypotheses testing. The research was cross-sectional because the data were undertaken randomly from a various call centre in Islamabad at one point of time.

\subsection{Data Analysis}

For proper data processing, entry and to find the results as output, SPSS (statistical package for social sciences) version 16.0 is the tool which is used in this research.

\subsection{Descriptive Statistics}

Table No.1 demonstrates the mean values for the respondents of this study. Out of which the mean value for the employment period stands to 1.9600 illustrating that on average less than 1 year employees are more than the rest ones. The mean value for the qualification stands 1.9900 illustrating that on average the study included Bachelors' respondents than other groups. Also, the mean value for the native language stands to 2.4400 illustrating that on average the study included Urdu speaking respondents than the rest. The mean value for the marital status stands to 1.7200 illustrating that on average the study included unmarried respondents than the married employees. The mean value for the gender stands to 1.3100 illustrating that on average the study included male respondents than the female employees. The mean value for the age stands to 1.5300 illustrating that on average the study included respondents between 2030 years than other employees.

Table 1: Mean

\begin{tabular}{|c|c|c|c|c|c|}
\hline $\begin{array}{l}\text { Demographic } \\
\text { Profile }\end{array}$ & $\underline{\text { Mean }}$ & $\underline{\text { Std. Deviation }}$ & $\underline{\text { Range }}$ & $\underline{\text { Minimum }}$ & $\underline{\text { Maximum }}$ \\
\hline $\begin{array}{l}\text { Employment } \\
\text { Period }\end{array}$ & 1.96 & 1.00423 & 3 & 1 & 4 \\
\hline Qualification & 1.99 & 0.8226 & 3 & 1 & 4 \\
\hline Native Language & 2.44 & 0.96735 & 4 & 1 & 5 \\
\hline Marital Status & 1.72 & 0.56995 & 1 & 1 & 4 \\
\hline
\end{tabular}

Sukkur IBA Journal of Management and Business | Volume 3 No. 2 July - December 2016 @ Sukkur Institute of Business Administration 
Rezwan Ullah et al. / Organization Justice and Organization Citizenship Behaviour: Employee Trust Acting as

\begin{tabular}{llllll}
\hline & & & & & \\
\hline Gender & 1.31 & 0.46482 & 1 & 1 & 2 \\
Age & 1.53 & 0.79715 & 4 & 1 & 5 \\
\hline
\end{tabular}

\subsection{Demographic Analysis}

This study included 100 respondents of call centre industry of Islamabad, Pakistan. In these respondents $41(41 \%)$ were less than 1-year employment period, $33(33 \%)$ were 1-2year, $15(15 \%)$ were a 2-3 year and $11(11 \%)$ were more than 3 years. Qualification shows that 29 (29\%) of the respondents lies in Intermediate level education. Bachelors' level employees were 48 (48\%), Master level were 18 (18\%) and the remaining 5 (5\%) were another level of education. Native Languages show that $16(16 \%)$ of the respondents were English speaking. 39 (39\%) of the respondents were Urdu speaking, $39(39 \%)$ were Punjabi, 9 (9\%) Pashto and other were 3 (3\%).Marital status shows that $32(32 \%)$ of the employees were married, $66(66 \%)$ were unmarried and the rest $4(4 \%)$ were other. Gender shows that 69 (69\%) of the employees were male and $31(31 \%)$ were female. A maximum number of respondents were between the ages of 20-30 years which makes them about $62(62 \%)$ of the respondents. $26(26 \%)$ of the respondents were from 30-40 years. $10(10 \%)$ of the respondent's lies between the age of 40-50 years, $1(1 \%)$ of the respondents were above the age of 50 and $1(1 \%)$ were others of the total respondents.

\section{Result and Discussion}

H1: Organizational Justice has positive impacts on OCB (Accepted)

Table 2: Model Summary

\begin{tabular}{|c|c|c|c|c|c|}
\hline \multirow{2}{*}{ Model 1} & \multirow{2}{*}{$\underline{\mathrm{R}}$} & \multirow{2}{*}{$\underline{\mathrm{R} \text { Square }}$} & \multirow{2}{*}{$\begin{array}{l}\text { Adjusted } \\
\underline{\text { Square }}\end{array}$} & $\mathrm{R}$ & Std. Error of the \\
\hline & & & & & Estimate \\
\hline 1 & 0.349 & 0.121 & 0.113 & & 4.25349 \\
\hline
\end{tabular}

The table above shows the relationship between organizational justice and organization citizenship behaviour. This table also shows the 1 units increase in organizational justice causes 34 units increase in organization citizenship behaviour.

Table 3: ANOVA

\begin{tabular}{llllll}
\hline Model 1 & $\underline{\text { Sum of Squares }}$ & $\underline{\text { Df }}$ & $\underline{\text { Mean Square }}$ & $\underline{F}$ & $\underline{\text { Sign. }}$ \\
\hline 1 Regression & 245.156 & 1 & 245.156 & 13.55 & 0 \\
Residual & 1773.034 & 98 & 18.092 & & \\
Total & 2018.19 & 99 & & & \\
\hline
\end{tabular}

a. Predictor: (Constant), OJ b. Dependent Variable: OCB 
This ANOVA Table tells the fitness of model. In the table, the regression sum of square value is less than the residual sum of the square but the value of $F$ is 13.550 and significant which tells model has achieved a fit to explain the relationship.

Table 4: Coefficients

\begin{tabular}{llllll} 
Model & $\begin{array}{l}\text { Unstandardized } \\
\text { Coefficients }\end{array}$ & & $\begin{array}{l}\text { Standardized } \\
\text { Coefficients }\end{array}$ & & \\
\cline { 2 - 7 } & $\underline{\mathrm{B}}$ & $\underline{\underline{\text { Std. }}}$ & $\underline{\text { Beta }}$ & $\underline{\mathrm{t}}$ & $\underline{\text { Sing. }}$ \\
\hline 1 (Constant) & 17.76 & 2.436 & & 7.29 & 0 \\
OJ & 0.201 & 0.055 & 0.349 & 3.681 & 0 \\
\hline
\end{tabular}

Dependent Variable: OCB

B is the regression coefficient. It tells the change brought in a direct variable (DV) when one unit of the indirect variable is changed. As per the table above the value of B is .201, which indicates that if organizational justice is increased by one unit it brings 17.760 units change in OCB. The value of $\mathbf{t}$ is 7.290 which are greater than 2 and the significance value is below the required range of 0.05 so it is confirmed that there is a significant relationship between organizational justice and organization citizenship behaviour.

H2: Procedural Justice has positive impacts on OCB. (Rejected)

Table 5: Model Summary

\begin{tabular}{|c|c|c|c|c|}
\hline Model & $\underline{\mathrm{R}}$ & $\underline{\mathrm{R} \text { Square }}$ & $\begin{array}{l}\text { Adjusted } \mathrm{R} \\
\underline{\text { Square }}\end{array}$ & $\begin{array}{l}\text { Std. Error of } \\
\text { the Estimate }\end{array}$ \\
\hline 1 & 0.255 & 0.065 & 0.055 & 4.38804 \\
\hline
\end{tabular}

a. Predictors: (Constant), PJ

The table above shows the relationship between procedural justice and organization citizenship behaviour. This table also shows the $1 \%$ increase in procedural justice causes $25 \%$ increase in organization citizenship behaviour.

Table 6: ANOVA Table

\begin{tabular}{lllllll}
\hline Model 1 & $\underline{\text { Sum }}$ & of & Df & $\underline{\text { Mean }}$ & F & $\underline{\text { Sign. }}$ \\
\hline
\end{tabular}


Rezwan Ullah et al. / Organization Justice and Organization Citizenship Behaviour: Employee Trust Acting as

\begin{tabular}{llllll}
\hline 1 & & & & & \\
\hline Regression & 131.206 & 1 & 131.206 & 6.814 & 0.01 \\
Residual & 1886.984 & 98 & 19.255 & & \\
Total & 2018.19 & 99 & & & \\
\hline
\end{tabular}

a. Predictor: (Constant), PJ b. Dependent Variable: OCB

This ANOVA Table tells the fitness of model. In the table, the regression sum of square value is less than the residual sum of the square but the value of $F$ is 6.814 and insignificant which tells model has not fit to explain the relationship.

H3: Distributional Justice has positive impacts on OCB. (Accepted)

Table 7: Model Summary

\begin{tabular}{|c|c|c|c|c|}
\hline Model 1 & R & R Square & $\begin{array}{l}\text { Adjusted } \mathrm{R} \\
\underline{\text { Square }}\end{array}$ & $\begin{array}{l}\text { Std. Error of } \\
\text { the Estimate }\end{array}$ \\
\hline 1 & 0.28 & 0.078 & 0.069 & 4.3567 \\
\hline
\end{tabular}

a. Predictors: (Constant), DJ

The table above shows the relationship between distributional justice and OCB. This table also shows the 1units increase in distributional justice causes 28 units increase in OCB.

Table8: ANOVA

\begin{tabular}{lllll}
\hline Model 1 & $\underline{\text { Sum of Squares }}$ & $\underline{\text { Df }}$ & $\underline{\text { Mean Square }}$ & $\underline{F}$ \\
\hline 1 Regression & 158.065 & 1 & 158.65 & 8.328 \\
Residual & 1860.125 & 98 & 18.981 & \\
\hline
\end{tabular}
a. Predictor: (Constant), DJ
b. Dependent Variable: OCB

This ANOVA Table tells that the model is fit. In the table, the regression sum of square value is less than the residual sum of the square but the value of $\mathrm{F}$ is .8 .328 which shows that the model is fit or significant which explains the relationship.

H4: Interactional Justice has positive impacts on OCB. (Accepted)

Table 9: Model Summary

\begin{tabular}{|c|c|c|c|c|}
\hline Model I & $\underline{\mathrm{R}}$ & $\underline{\mathrm{R} \text { Square }}$ & $\begin{array}{l}\text { Adjusted } \mathrm{R} \\
\text { Square }\end{array}$ & $\begin{array}{l}\text { Std. Error of } \\
\text { the Estimate }\end{array}$ \\
\hline 1 & 0.26 & 0.068 & 0.058 & 4.38142 \\
\hline
\end{tabular}

a. Predictors: (Constant), IJ $\quad$ b. Dependent Variable: OCB

Sukkur IBA Journal of Management and Business | Volume 3 No. 2 July - December 2016 @ Sukkur Institute of Business Administration 
Rezwan Ullah et al. / Organization Justice and Organization Citizenship Behaviour: Employee Trust Acting as

The table above shows the relationship between institutional justice and OCB. This table also shows the 1units increase in institutional justice causes 26 units increase in OCB.

Table 10: ANOVA

\begin{tabular}{|c|c|c|c|c|}
\hline Model 1 & $\underline{\text { Sum of Squares }}$ & $\underline{\mathrm{Df}}$ & Mean Square & $\underline{F}$ \\
\hline 1 Regression & 136.9 & 1 & 136.9 & 7.131 \\
\hline Residual & 1881.29 & 98 & 19.197 & \\
\hline
\end{tabular}
a. Predictor: (Constant), IJ
b. Dependent Variable: OCB

This ANOVA Table tells that the model is fit. In the table, the regression sum of square value is less than the residual sum of the square but the value of $F$ is 7.131 which shows that the model is fit or significant which explains the relationship.

Table 11: Coefficients

\begin{tabular}{|c|c|c|c|c|c|}
\hline \multirow[t]{2}{*}{ Mode 1} & \multicolumn{2}{|l|}{$\begin{array}{l}\text { Unstandardized } \\
\text { Coefficients }\end{array}$} & \multicolumn{3}{|l|}{$\begin{array}{l}\text { Standardized } \\
\text { Coefficients }\end{array}$} \\
\hline & $\underline{B}$ & $\frac{\text { Std. }}{\text { Error }}$ & $\underline{\text { Beta }}$ & $\underline{\mathrm{t}}$ & Sing. \\
\hline 1 (Constant) & 21.582 & 1.926 & & 11.207 & .000 \\
\hline IJ & .263 & .099 & .260 & 2.670 & .009 \\
\hline
\end{tabular}

a. Dependent Variable: OCB

B is the regression coefficient. As per the table above the value of B is 21.582 , which indicates a positive relationship between institutional justice and OCB. The value of $\mathbf{t}$ is 11.207 which are greater than 2 which show the model fitness and the significance value is .000 so researcher confirms this hypothesis that there is a positive relationship.

H5: Employee trust mediates the associations between Organizational Justice and $O C B$, which is a positive impact on OCB. (Rejected)

Table 12: Model Summary

\begin{tabular}{lllll}
\hline Model I & R & R Square & $\begin{array}{l}\text { Adjusted } \\
\text { Square }\end{array}$ & $\begin{array}{c}\text { R } \\
\text { Std. Error of } \\
\text { the Estimate }\end{array}$ \\
\cline { 2 - 5 } 1 & 0.366 & 0.134 & 0.116 & 4.42781 \\
\hline
\end{tabular}

a. Predictors: (Constant), OCB, OJ 
The table above shows the relationship between organization justice and OCB and the mediating role of employment trust. This table also shows the lunits increase in organization justice causes 36 units increase in OCB.

Table 13: ANOVA

\begin{tabular}{lllll} 
Model 1 & Sum of Squares & Df & Mean Square & $\underline{F}$ \\
\hline 1 Regression & 295.016 & 2 & 147.508 & 7.524 \\
Residual & 1901.734 & 97 & 19.606 &
\end{tabular}
a. Predictor: (Constant), OCB, OJ
b. Dependent Variable: Employment Trust

This ANOVA Table tells that the model is fit. In the table, the regression sum of square value is less than the residual sum of the square but the value of $F$ is 7.524 which shows that the model is fit or significant which explains the relationship.

Table 14: Coefficients

\begin{tabular}{|c|c|c|c|c|c|}
\hline \multirow[t]{2}{*}{ Model } & \multicolumn{2}{|l|}{$\begin{array}{l}\text { Unstandardized } \\
\text { Coefficients }\end{array}$} & \multicolumn{2}{|l|}{$\begin{array}{l}\text { Standardized } \\
\text { Coefficients }\end{array}$} & \multirow[b]{2}{*}{ Sing. } \\
\hline & $\underline{B}$ & $\begin{array}{l}\text { Std. } \\
\text { Error }\end{array}$ & Beta & $\underline{\mathrm{t}}$ & \\
\hline 1 (Constant) & 3.023 & $\overline{3.149}$ & & .960 & .340 \\
\hline OJ & .223 & .061 & .371 & 3.681 & 0.000 \\
\hline OCB & -.014 & .105 & -.014 & -.136 & .892 \\
\hline
\end{tabular}

a. Dependent Variable: Employment Trust

$\mathrm{B}$ is the regression coefficient. It tells the change brought in a direct variable (DV) when one unit of the indirect variable is changed. As per the table above the value of B for OP is .223, which indicates that if organizational justice is increased by one unit it brings 22.3 units change in OCB. The value of $t$ is 3.681 which are greater than 2 which show the model fitness and the significance value is below the required range of .05 but the value of $\mathrm{B}$ for OCB -.014, which indicates a negative relationship. The value of $t$ is -.136 which is less than 2 which shows that model is not fit and significance value is greater than the required range .05 which is insignificant, so researcher confirms this hypothesis that there is an insignificant relationship between organizational justice and OCB.

\section{Conclusion}

This study can assist the management of call centre industry for enhancing the association between organizational justice and organizational citizenship behaviour of employees at the workplace. As a result, it has been proved that there is a positive 
impact among organizational Justice, distributional justice and interactional justice with organizational citizenship behaviour and negative impact with distributional justice. This study demonstrates that there is no mediation effect between organizational justice and OCB due to employment trust.

\section{Recommendation}

Employees are the key resource for every organization. Employee behaviour affects from organizational justice because every employee has desires to be treated fairly in his workplace. In order to investigate in the Call centre industry, in general, these behaviours should be promoted. This is important to see the employee trust on the management and organization as well. On the basis of the analysis, the following recommendations were made.

The findings emphasize the importance of organizational justice dimensions and can help the management to improve their decision-making; to develop an environment of trust; effective rewards system, procedure evaluation system, and the proper information system should be developed to cope the organizational citizenship behaviour and call centre industry management should make their employees believe that they are valuable for the Call Centre Industry.

\section{Limitations}

The sample was collected only from Call service agents and call centre management; the data were only collected through questionnaire and no interview and discussion were made and the results provide additional support for several other types of research from different countries.

\section{References}

Adams, J. S. (1965). Inequity in social exchange. Advances in experimental social psychology, 2, 267-299.

Ang, S., Van Dyne, L., \& Begley, T. M. (2003). The employment relationships of foreign workers versus local employees: A field study of organizational justice, job satisfaction, performance, and OCB. Journal of organizational Behavior, 24(5), 561-583.

Aryee, S., Budhwar, P. S., \& Chen, Z. X. (2002). Trust as a mediator of the relationship between organizational justice and work outcomes: Test of a social exchange model. Journal of organizational Behavior, 23(3), 267-285.

Aslam, R., \& Sadaqat, S. (2011). Investigating the relationship of organizational justice on organizational citizenship behavior among teaching staff of University of the Punjab. European Journal of Scientific Research, 57(1), 53-67.

Cohen-Charash, Y., \& Spector, P. E. (2001). The role of justice in organizations: A meta-analysis. Organizational behavior and human decision processes, 86(2), 278-321.

Sukkur IBA Journal of Management and Business | Volume 3 No. 2 July - December 2016 @ Sukkur Institute of Business Administration 
Colquitt, J. A., Conlon, D. E., Wesson, M. J., Porter, C. O., \& Ng, K. Y. (2001). Justice at the millennium: a meta-analytic review of 25 years of organizational justice research: American Psychological Association.

Colquitt, J. A., Greenberg, J., Zapata-Phelan, C. P., Greenberg, J., \& Colquitt, J. A. (2005). What is organizational justice? A historical overview. Handbook of organizational justice, 1, 3-58.

Cropanzano, R., Ambrose, M. L., Greenberg, J., \& Cropanzano, R. (2001). Procedural and distributive justice are more similar than you think: A monistic perspective and a research agenda. Advances in organizational justice, 119, 151.

Deluga, R. J. (1994). Supervisor trust building, leader-member exchange and organizational citizenship behaviour. Journal of occupational and Organizational Psychology, 67(4), 315-326.

Fox, A. (1974). Beyond contract: Work, power and trust relations: Faber \& Faber.

Gouldner, A. W. (1960). The norm of reciprocity: A preliminary statement. American sociological review, 161-178.

Greenberg, J. (1987). A taxonomy of organizational justice theories. Academy of Management review, 12(1), 9-22.

Greenberg, J. (1990). Organizational justice: Yesterday, today, and tomorrow. Journal of management, 16(2), 399-432.

Greenberg, J. (2002). Advances in organizational justice: Stanford University Press.

Greenberg, J. (2005). Managing behavior in organizations: Prentice Hall.

Greenberg, J., \& Baron, R. A. (2008). Behavior in organizations.

Hodson, R. (2002). Management citizenship behavior and its consequences. work and occupations, 29(1), 64-96.

James, K. (1993). The social context of organizational justice: Cultural, intergroup, and structural effects on justice behaviors and perceptions. Justice in the workplace: Approaching fairness in human resource management, 21-50.

Leventhal, G. S. (1976). The distribution of rewards and resources in groups and organizations. Advances in experimental social psychology, 9, 91-131.

Lewicki, R. J., Wiethoff, C., Tomlinson, E. C., Greenberg, J., \& Colquitt, J. (2005). What is the role of trust in organizational justice. Handbook of organizational justice, 247-270.

Loi, R., Hang-Yue, N., \& Foley, S. (2006). Linking employees' justice perceptions to organizational commitment and intention to leave: The mediating role of perceived organizational support. Journal of occupational and Organizational Psychology, 79(1), 101-120.

McFarlin, D. B., \& Sweeney, P. D. (1992). Research notes. Distributive and procedural justice as predictors of satisfaction with personal and organizational outcomes. Academy of management Journal, 35(3), 626-637.

Organ, D. W. (1988). Organizational citizenship behavior: The good soldier syndrome: Lexington Books/DC Heath and Com.

Organ, D. W., Podsakoff, P. M., \& MacKenzie, S. B. (2005). Organizational citizenship behavior: Its nature, antecedents, and consequences: Sage Publications. 
Smith, C., Organ, D. W., \& Near, J. P. (1983). Organizational citizenship behavior: Its nature and antecedents. Journal of applied psychology, 68(4), 653.

Thibaut, J., \& Walker, L. (1978). A theory of procedure. California law review, 541566.

Williams, L. J., \& Anderson, S. E. (1991). Job satisfaction and organizational commitment as predictors of organizational citizenship and in-role behaviors. Journal of management, 17(3), 601-617.

Zand, D. E. (1996). The leadership triad: Knowledge, trust, and power: Oxford University Press. 